\title{
IAMJ
}

INTERNATIONAL

AYURVEDIC

MEDICAL JOURNAL

\section{EFFICACY OF ERANDAMOOLADI BASTI IN THE MANAGEMENT OF JANU SANDHIGATAVATA VIS-A-VIS OSTEOARTHRITIS OF KNEE JOINT - AN OBSERVATIONAL CLINICAL STUDY}

\author{
S Jagadesh Kumar ${ }^{1}$, Shreyas D $\mathbf{M}^{2}$, Kiran M Goud ${ }^{3}$ \\ ${ }^{1}$ PG Scholar, Dept of Panchakarma, Sri Kalabyraveshwara Swamy Ayurvedic Medical College, Hospital \& \\ Research Center, Bengaluru, Karnataka, India \\ ${ }^{2}$ Assistant Professor, Dept of Panchakarma, Sri Kalabyraveshwara Swamy Ayurvedic Medical College, Hospital \& \\ Research Center, Bengaluru, Karnataka, India \\ ${ }^{3}$ Professor \& Principal, Dept of Panchakarma, Sri Kalabyraveshwara Swamy Ayurvedic Medical College, \\ Hospital \& Research Center, Bengaluru, Karnataka, India
}

Corresponding Author: jagadeshrocky@gmail.com

\section{https://doi.org/10.46607/iamj0609022021}

(Published online: February 2021)

Open Access

(C) International Ayurvedic Medical Journal, India 2021

Article Received: 28/01/2021 - Peer Reviewed: 01/02/2021 - Accepted for Publication: 02/02/2021

\section{A) Check for updates}

\begin{abstract}
Janu Sandhigata vata is one such Vatavyadhi presenting with Sandhi shula, Sandhi shotha, Sandhi atopa and Prasarana Akunchana Vedana, resulting in limited range of movements, there by restricting daily activities of the individual. Janu Sandhigatavata is commonly identified with Osteoarthritis of Knee Joint characterized by pain, swelling \& impaired movements. The prevalence of Osteoarthritis rises progressively with age and it has been estimated that that $45 \%$ of all people develop Knee Osteoarthritis in life. Osteoarthritis is more common in women than men. The existent line of treatment in contemporary field of medicine includes the administration of analgesics, NSAIDS, Intra articular steroids and surgical intervention in the form of Knee replacement, which all has their own limitation and meanwhile may have deleterious adverse effect. In this regard, there is a need for exploring the safe, effective and affordable line of treatment. Basti karma is a supreme treatment for Vata Vyadhi and also known as Ardha Chikitsa because of its multifaceted actions. Many Basti formulations are mentioned in classics among which
\end{abstract}


Erandamooladi Bati was selected for the study because its dual action, does Vataghna and also relives Kapha Avarana. The results were statistically highly significant within the group.

Keywords: Janu Sandhigata Vata, Osteoarthritis of Knee joint, Basti karma, Erandamoola Basti

\section{INTRODUCTION}

Janu Sandhigata Vata is a condition, in which vitiated Vayu gets localized in Janu Sandhi and causes shula, shotha, stambha, Prasarna Akunchana Vedana and Atopa. ${ }^{1}$ It can be compared to osteoarthritis of kneejoint, according to modern parlance. Osteoarthritis is characterized by Pain, Stiffness, Swelling in joints, restricted movements and Crepitus. The prevalence of Osteoarthritis rises progressively with age, such that by 65 years $80 \%$ of people have radiographic evidence of Osteoarthritis, though only $25-30 \%$ are symptomatic. The knee and hip are the principle large joints involved; affecting $10-25 \%$ of those aged over 65 years. $^{2}$ Snehana and Swedana occupy the major place in the domain of Samanya Chikitsa of Vata Vyadhi. ${ }^{3}$ Basti karma is considered as the best line of treatment for Vata Vyadhi. It has considered as prime Chikitsa for Vata vikaras. There is a wide applicability of Basti Chikitsa like Shodhana, Shamana, Brhumana and Lekhana etc based on the properties of the drugs used in the procedure. Here, in this present study Erandamooladi Basti (in Yoga Basti) has been employed, as Sandhigata Vata is one of the degenerative disorders and there will be Kshaya of Snehamsha i.e. Shleshaka Kapha in the Sandhi and can be associated kapha avarana. Erandamooladi Basti is having Vatahara, relives kapha avarana and Brihmana action nourishes the Dhatu and helps in reliving Shoola and stiffness of Janu, and also helps in maintaining joints in stable condition by avoiding further Degeneration.

\section{Aim and Objectives:}

- To evaluate the efficacy of Erandamooladi basti in the management of Janu Sandhigata Vata Vis-AVis Osteoarthritis of Knee joint.

\section{Materials and Methods:}

\section{Source of Data:}

Total 20 Subjects with clinical features of Janu Sandhigata Vata Vis-A-Vis Osteoarthritis of Knee joint coming under the inculsion criteria approaching the out-patient and in-patient department of Sri Kalabyraveshwaraswamy Ayurvedic Medical College, Hospital \& Research centre, Bengaluru were selected for the study.

\section{Diagnostic criteria:}

- Based on Lakshanas of Janu sandhigata vata

- Signs and symptoms of Osteoarthritis of Knee joint $^{4}$

- Based on radiological evidence of Osteoarthritis of Knee joint

\section{Inclusion criteria:}

- Subject presenting with Lakshanas of Janu sandhigata vata

- Subject presenting with Signs and symptoms of Osteoarthritis of Knee joint

- Subject presenting with radiological evidence of Osteoarthritis of Knee joint

- Subject of either gender from the age group of 4070 years

- Subject fit for Basti Karma

Exclusion criteria:

- Any systemic illness that interfere with the course of intervention

- Pregnant and lactating women

\section{Study design:}

- Single arm, active, open label clinical study

Intervention: Subjects was administered Erandamooladi basti in Yoga Basti pattern.

\section{Poorva Karma}

\section{a. Method of preparation of Erandamooladi basti:}

Madhu $40 \mathrm{ml}$ was taken in Kalwa and 10 grams of Saindhava Lavana was added to it \& Continuous churning was done to make a homogenous mixture., to that homogenous mixture - $100 \mathrm{ml}$ of Murchita tila taila was added slowly and stirring was continued until a uniform consistency was attained. Later 30 gram of Rasna Kalka churna was taken and lukewarm water is 
added and made in to semisolid consistency and this was added to the above mixture, Kwatha made out of Erandamoola Kwatha choorna was filtered through a fine sieve then added slowly and part by part for proper mixing., Finally $200 \mathrm{ml}$ of Aja mamsa rasa was added very slowly while the churning process is continued.

\section{b. Preparation of patient (Athura Siddatha):}

Abhyanga-Sthanika Abhyanga was administered with Moorchita tila taila followed by Sthanika Nadi Sweda to Shroni, Kati, Vankshana, Pakwashaya Pradesha. Swedana - Nadi Sweda with Ushna jala. Anuvasana Basti- Given after Laghu Ahara Sevana, Erandamooladi Basti - Given in empty Stomach

\section{Pardhana Karma}

- Patient is asked to lie in left lateral position.

- Anuvasana and Niruha basti are given alternately as per Yoga Basti pattern shown in table.

1. Anuvasana Basti - moorchita taila - $80 \mathrm{ml}$ (After consuming Laghuaahara)

Table 1: Showing the pattern of Yoga Basti

\begin{tabular}{|l|l|l|l|l|l|l|l|l|}
\hline Day & 1 st & 2nd & $3^{\text {rd }}$ & 4 th & $5^{\text {th }}$ & 6 th & 7 th & 8 th \\
\hline Basti & A & N & A & N & A & N & A & A \\
\hline
\end{tabular}

2. Niruha basti - Erandamooladi basti. (On empty stomach at 7am)

\begin{tabular}{|l|l|}
\hline Table 2: Showing Niruha Basti ingredients & $40 \mathrm{ml}$ \\
\hline Madhu & $10 \mathrm{gms}$ \\
\hline Saindhava lavana & $100 \mathrm{ml}$ \\
\hline Moorchita taila & $30 \mathrm{gms}$ \\
\hline Rasna Kalka & $300 \mathrm{ml}$ \\
\hline Erandamoola kwatha & $200 \mathrm{ml}$ \\
\hline Aja mamsa rasa & \\
\hline
\end{tabular}

\section{Paschat Karma}

Anuvasana Basti: Patients were made to lie down in supine position for 100 Matrakala, patting of buttocks, raising the legs (3 times each) was performed in order to retain the Sneha inside for a longer period.
Niruha Basti: After this the patient was asked to lie in a comfortable position on the Droni with his body in raised position by means of pillow in such a way that Veerya of the Basti may spread throughout the body.

\section{Assessment criteria}

Assessment was done on BT (Before treatment) \& AT (After the treatment)

Table 3: Showing Grading of Subjective parameters:

\begin{tabular}{|l|l|l|l|l|l|}
\hline $\begin{array}{l}\text { Assessment } \\
\text { Criteria }\end{array}$ & $\begin{array}{l}\text { Prakrutha } \\
\text { (Normal) (0) }\end{array}$ & $\begin{array}{l}\text { Mrudu } \\
\text { (Mild) (1) }\end{array}$ & $\begin{array}{l}\text { Madhyama } \\
\text { (Moderate) (2) }\end{array}$ & $\begin{array}{l}\text { Daruna (severe) } \\
\text { (3) }\end{array}$ & $\begin{array}{l}\text { Ati daruna (Extremely } \\
\text { severe) (4) }\end{array}$ \\
\hline Sandhi Shula & No pain & $\begin{array}{l}\text { Occasion al } \\
\text { pain }\end{array}$ & $\begin{array}{l}\text { Pain during excess } \\
\text { work }\end{array}$ & $\begin{array}{l}\text { Constant pain } \\
\text { disturbing } \\
\text { Routine }\end{array}$ & Severe pain \\
\hline Sandhi Shotha & No swelling & $\begin{array}{l}\text { Mild } \\
\text { swelling }\end{array}$ & $\begin{array}{l}\text { Slight more when } \\
\text { compared to } \\
\text { milder one }\end{array}$ & $\begin{array}{l}\text { Covers all } \\
\text { prominence s of } \\
\text { affected } \\
\text { joints }\end{array}$ & $\begin{array}{l}\text { Elevated joint seems } \\
\text { grossly deformed }\end{array}$ \\
\hline Sandhi Stabdata & No Stiffness & Stiffness & Stiffness (15-30 & Stiffness (30 mins & Constant Stiffness \\
\hline
\end{tabular}




\begin{tabular}{|c|c|c|c|c|c|}
\hline & & $\begin{array}{l}(5 \mathrm{~min}- \\
15 \mathrm{mins})\end{array}$ & mins) & $\begin{array}{l}- \\
1 \mathrm{hr})\end{array}$ & \\
\hline $\begin{array}{l}\text { Prasarana } \\
\text { Akunchana } \\
\text { Vedana }\end{array}$ & $\begin{array}{l}\text { No painful } \\
\text { movement }\end{array}$ & $\begin{array}{l}\text { Pain without } \\
\text { wincing } \\
\text { of face }\end{array}$ & $\begin{array}{l}\text { Pain with wincing } \\
\text { of face }\end{array}$ & $\begin{array}{l}\text { Shouts / prevents } \\
\text { complete } \\
\text { flexion }\end{array}$ & $\begin{array}{l}\text { Does not allow passive } \\
\text { movements }\end{array}$ \\
\hline
\end{tabular}

Table 4: Showing Grading of Objective parameter:

\begin{tabular}{|l|l|l|l|l|l|}
\hline Assessment criteria & None & Mild & Moderate & Severe & Extreme \\
\hline Sandhi Atopa & No & Mild Palpable & Moderate Palpable & Severe Palpable & Audible \\
& Crepitus & Crepitus & Crepitus & Crepitus & Crepitus \\
\hline
\end{tabular}

\section{Observations:}

Total number of Subjects registered for the study -23

Total number of Subjects completed the study -20

Total number of Droupouts - 3

Distribution of Subjects based on Age (years): In the present study, 7(35\%) Subjects were belonged to age group of 51-60 years, 13(65\%) Subjects were belonged to age group of 61-70 years.

Distribution of Subjects based on Gender: In the present study, 14(70\%) Subjects were Females, 6(30\%) Subjects were Males.

Distribution of Subjects based on Janusandhi Shoola: In the present study, 1(10\%)Subjects had Janusandhi Shoola in right knee joint, 1(10\%)Subjects had Janusandhi shoola in left knee joint, 18(80\%) Subjects had Janusandhi Shoola in both the knee joint. Statistical Analysis:

- For the Statistical analysis, the data obtained in both the groups were recorded and presented in tabulations and graphs.

- The assessment was done Before treatment (BT) and After treatment (AT) and the assessment parameters like Sandhi Shula, Sandhi Shotha, Sandhi Stabdata, Prasarana Pravrutta Vedana, AkunchanaPravrutta Vedana were subjected to Wilcoxon Signed Rank Test.

- The assessment parameter Sandhi Atopa was subjected to Paired ' $t$ ' test

\begin{tabular}{|l|l|}
\hline Interpretation & P Value \\
\hline Insignificant & $>0.005$ \\
\hline Significant & $<0.005$ \\
\hline Highly Significant & $<0.01,<0.001$ \\
\hline
\end{tabular}

\section{Results:}

\begin{tabular}{|c|c|c|c|c|c|c|c|c|c|c|}
\hline BT-AT & $\mathrm{M}$ & SD & SEM & $\begin{array}{l}\text { Wilcoxon } \\
\text { Signed Rank }\end{array}$ & $\mathrm{N}$ & MR & SR & $\begin{array}{l}Z \\
\text { Value }\end{array}$ & $\begin{array}{r}\mathrm{P} \\
\text { Value }\end{array}$ & $\mathrm{Re}$ \\
\hline \multirow[b]{3}{*}{ BT-AT } & \multirow[b]{3}{*}{2.00} & \multirow[b]{3}{*}{0.55} & \multirow[b]{3}{*}{0.08} & NR & 4 & \multirow[b]{3}{*}{20.50} & \multirow[b]{3}{*}{820.00} & \multirow[b]{3}{*}{-5.75} & \multirow[b]{3}{*}{$<0.001$} & \multirow[b]{3}{*}{ HS } \\
\hline & & & & PR & 0 & & & & & \\
\hline & & & & Ties & 0 & & & & & \\
\hline
\end{tabular}

In the present study, the Wilcoxon Signed Rank Test on Janu Sandhi Shula revealed statistically highly significant result with $Z$ value -5.75 and $p$ value $<0.001$. 
Table 6: Effect of treatment on Janu Sandhi Shotha

\begin{tabular}{|c|c|c|c|c|c|c|c|c|c|c|}
\hline Phase & $\mathbf{M}$ & SD & SEM & $\begin{array}{l}\text { Wilcoxon Signed } \\
\text { Rank }\end{array}$ & $\mathbf{N}$ & MR & SR & Z Value & P Value & $\mathbf{R e}$ \\
\hline \multirow[t]{3}{*}{ BT-AT } & \multirow[t]{3}{*}{1.52} & \multirow[t]{3}{*}{0.64} & \multirow[t]{3}{*}{0.10} & NR & 20 & \multirow[t]{3}{*}{20.00} & \multirow[t]{3}{*}{780.00} & \multirow[t]{3}{*}{-5.58} & \multirow[t]{3}{*}{0.001} & \multirow[t]{3}{*}{ HS } \\
\hline & & & & PR & 0 & & & & & \\
\hline & & & & Ties & 0 & & & & & \\
\hline
\end{tabular}

The Wilcoxon Signed Rank Test on Janu Sandhi Shotha revealed statistically highly significant result with $\mathrm{Z}$ value -5.58 and $\mathrm{p}$ value $<0.001$.

Table 7: Effect of treatment on Janu Sandhi Stabdata

\begin{tabular}{|c|c|c|c|c|c|c|c|c|c|c|}
\hline Phase & $\mathbf{M}$ & SD & SEM & $\begin{array}{l}\text { Wilcoxon } \\
\text { Signed Rank }\end{array}$ & $\mathbf{N}$ & MR & SR & Z Value & P Value & $\mathbf{R e}$ \\
\hline \multirow[t]{3}{*}{ BT-AT } & \multirow[t]{3}{*}{1.65} & \multirow[t]{3}{*}{0.66} & \multirow[t]{3}{*}{0.10} & NR & 40 & \multirow[t]{3}{*}{20.50} & \multirow[t]{3}{*}{820.00} & \multirow[t]{3}{*}{-5.63} & \multirow[t]{3}{*}{$<0.001$} & \multirow[t]{3}{*}{ HS } \\
\hline & & & & PR & 0 & & & & & \\
\hline & & & & Ties & 0 & & & & & \\
\hline
\end{tabular}

The Wilcoxon Signed Rank Test on Janu Sandhi Stabdata revealed statistically highly significant result with $\mathrm{Z}$ value -5.63 and $\mathrm{p}$ value $<0.001$.

Table 8: Effect of treatment on Prasarana Pravrutta Vedana

\begin{tabular}{|c|c|c|c|c|c|c|c|c|c|c|}
\hline Phase & $\mathbf{M}$ & SD & SEM & $\begin{array}{l}\text { Wilcoxon } \\
\text { Signed Rank }\end{array}$ & $\mathbf{N}$ & MR & SR & Z Value & P Value & $\mathbf{R e}$ \\
\hline \multirow[t]{3}{*}{ BT-AT } & \multirow[t]{3}{*}{2.07} & \multirow[t]{3}{*}{0.79} & \multirow[t]{3}{*}{0.12} & $\mathrm{NR}$ & 40 & \multirow[t]{3}{*}{20.50} & \multirow[t]{3}{*}{820.00} & \multirow[t]{3}{*}{-5.66} & \multirow[t]{3}{*}{0.001} & \multirow[t]{3}{*}{ HS } \\
\hline & & & & PR & 0 & & & & & \\
\hline & & & & Ties & 0 & & & & & \\
\hline
\end{tabular}

The Wilcoxon Signed Rank Test on Prasarana Pravrutta Vedana revealed statistically highly significant result with $Z$ value -5.66 and $p$ value $<0.001$.

Table 9: Effect of treatment on Janu Sandhi Atopa

\begin{tabular}{|l|l|l|l|l|l|l|l|l|}
\hline \multirow{2}{*}{ Phase } & Mean & MT & MD & SD & SEM & T Value & P Value & Re \\
\cline { 2 - 9 } & BT & AT & & & & & \\
\hline BT-AT & 2.75 & 0.95 & 1.80 & 0.82 & 0.13 & 13.83 & 0.001 & HS \\
\hline
\end{tabular}

Paired t test on Janu Sandhi Atopa revealed statistically highly significant result with $\mathrm{t}$ value 13.83 and $\mathrm{p}$ value $<0.001$.

\section{DISCUSSION}

Among three Doshas, vata is the prime Dosha responsible in the manifestation of the disease. Sandhigata vata is one among the Vata vyadhi explained by our Acharyas, predominance of Vata Dosha is seen in old age which is further aggravated due to Dhatu kshaya that takes place as the age advances. Acharya Sushrutha is Specific in mentioning of commencement of degenerative changes that is after 40years which is termed as Parihani Avastha of madhyama Vaya, where the individual starts to develop tendency to suffer from Vata Vyadhi. If at this stage person indulges in Vata kara Ahara vihara there will be a prakopa of vata and this prakaupita vata takes asharaya in Khavaigunya yukta srotas. Here it is (Janu sandhi) and causes depletion of bodily elements. As Shleshma bhava in sandhi is reduced leading to pain in joints.

When Basti is introduced into the Pakwashaya, the Veerya of Basti reaches all over the body, collects the 
accumulated Doshas and Shakrut from Nabhi, Kati, Parshwa and Kukshi pradesha, causes Snehana to the body and expels out the Dosha along with Pureesha ${ }^{5}$. Pakwashaya, which is the seat of Vata dosha, can be correlated to Pureeshadhara-kala. According to Dalhana, Pureeshadara kala itself is Astidharakala ${ }^{6}$. This establishes a relationship between the large intestine and bones. Basti is having 2 actions; Veerya of Dravya should get absorbed to have its systemic action. Second major action is related with the facilitation of excretion of morbid Doshas responsible for disease into colon from where they are evacuated. All these actions can be well explained on the basis of physiological and pharmacological actions.

Effect from Anuvasana basti: Anuvasana basti will retain the oil for a specific period without causing any adverse effect. It protects Pureeshadhara kala by giving Snehana effect. Tila Taila having Ushna veerya and Guru, Snigdha guna ${ }^{7}$ combats Ruksha and Laghu guna of Vata, ${ }^{8}$ which in turn does Vata shamana.

Effect from Niruha basti: Madhu having Yogavahi and Sukshma marga anusarita ${ }^{9}$ property acts as catalyst and penetrates into the Sukshma srotas. Saindhava lavana having Laghu and Tridosha Shamaka guna ${ }^{10}$ was added to it. Sneha dravya, Taila having Ushna veerya, Snigdha guna ${ }^{l 1}$ combats Ruksha and Laghu guna of Vata $^{12}$, which inturn causes Vata shamana. Kalka is the main drug, which gives potency to the whole combination. It helps to disintegrate the Malas. Kwatha does Anulomana and Nirharana of Doshas. Erandamula niruha basti is Vataghna and is indicated in Jangha, Uru pada, Prushta Shula hara ${ }^{13}$. Eranda being main ingredient, has Snigdha, Sukhsma and Teekshna properties does Srotoshodhana and thus acts as Vatahara, Balya and Vedhanasthapana. ${ }^{14}$ Hence considering the properties of all the ingredients, Erandamooladi basti is effective in treating Janusandhigata Vata.

\section{CONCLUSION}

Present study Erandamooladi basti proved to be effective in reducing Lakshanas of Janusandhigata Vata and has shown good results in all assessment parameters taken into consideration. The study suggests Erandamooladi basti can be taken as better choice of treatment in the management of Janu Sandhigatavata Vis-A-Vis Osteoarthritis of Knee joint. The study can be taken up for further study on large sample.

\section{REFERENCES}

1. Agnivesha, Charaka, Drudabala, Chakrapanidatta. Chikitsa Sthana, Chapter 28, Verse.37. In: Acharya Y T (Edi.), Charaka Samhita with Ayurveda Deepika Commentary. Reprint Edition, 2011. Varanasi: Chowkhamba Surabharati Prakashan: 2011.p.618.

2. S.H.Ralston, I.B.Mcinnes, Chapter 25 , Rheumatology \& Bone disease, In: Brian R. Walker, Nicki R. Colledge, Stuart H. Ralstor (Edi.).Davidsons principals \& Practice of medicine, $22^{\text {nd }}$ edition, China: Churchill livingstone Elsevier: 2014.p.1083.

3. Agnivesha, Charaka, Drudabala, Chakrapanidatta. Chikitsa Sthana, Chapter 28, Verse.75-82. In: AcharyaY T(Edi.), Charaka Samhita with Ayurveda Deepika Commentary. Reprint Edition, 2011. Varanasi: Chowkhamba Surabharati Prakashan: 2011.p.620.

4. S.H. Ralston, I.B. Mcinnes, Chapter 25, Rheumatology \& Bone disease, In: Brian R. Walker, Nicki R. Colledge, Stuart H. Ralstor (Edi.). Davidsons principals \& Practice of medicine, $22^{\text {nd }}$ edition, China: Churchill livingstone Elsevier: 2014.p.1083.

5. Agnivesha, Charaka, Drudabala, Chakrapanidatta. Siddhi Sthana, Chapter 1, Verse.40. In: Acharya Y T(Edi.), Charaka Samhita with Ayurveda Deepika Commentary. Reprint Edition, 2011. Varanasi: Chowkhamba Surabharati Prakashan: 2011.p.684.

6. Sushruta, Dalhana, Gayadasa. Kalpa Sthana Chapter 4 Verse 40. In: Acharya YT, Narayana Ram (Edi.). Sushrutha Samhitha with Nibandhasangraha, Nyayachandrika Commentary. Reprint Edition. 2017.Varanasi: Chaukhamba Sanskrit Sansthaan. p. 574.

7. Agnivesha, Charaka, Drudabala, Chakrapanidatta. Sutra Sthana, Chapter 27, Verse. 286. In: Acharya Y T(Edi.), Charaka Samhita with Ayurveda Deepika Commentary. Reprint Edition, 2011. Varanasi: Chowkhamba Surabharati Prakashan: 2011.p.169.

8. Vagbhata, Astanga sangraha with the sanskrit commentary Sasilekha by Indhu, edited by; Dr. Shivprasad Sharma, chaukhambha Sanskrit series office, Varanasi, Sutra sthana, 6th chapter, shloka 92. 
9. Astanga Sangraha with the commentaries of Sarvangasundara of Arunadatta and Ayurvedarasayana of Hemadri, edited by; Pandit. Bhishgacharya Harishastri Paradkar Vaidya, Chaukhambha Orientalla, Varanasi, Reprint 2015, Sutra sthana, 6thchapter, Shloka 92.

10. Agnivesha, Charaka, Drudabala, Chakrapanidatta.Sutra Sthana, Chapter 27, Verse.300. In: Acharya Y T(Edi.), Charaka Samhita with Ayurveda Deepika Commentary. Reprint Edition, 2011. Varanasi: Chowkhamba Surabharati Prakashan: 2011.p.170.

11. Agnivesha, Charaka, Drudabala, Chakrapanidatta. Sutra Sthana, Chapter 27, Verse. 286. In: Acharya Y T(Edi.), Charaka Samhita with Ayurveda Deepika Commentary. Reprint Edition, 2011. Varanasi: Chowkhamba Surabharati Prakashan: 2011.p.169.

12. Vagbhata, Astanga sangraha with the commentaries of sarvangasundara of Arunadatta and Ayurvedarasayana of Hemadri, edited by; Pandit. Bhishgacharya Harishastri Paradkar Vaidya chaukhambha orientalla, Varanasi, Reprint 2015, Sutra sthana, 1st chapter, shloka 10.

13. Agnivesha, Charaka, Drudabala, Chakrapanidatta. Siddhi Sthana, Chapter 1, Verse.40. In: AcharyaY T(Edi.), Charaka Samhita with Ayurveda Deepika Commentary. Reprint Edition, 2011. Varanasi: Chowkhamba Surabharati Prakashan: 2011.p.684.

14. Agnivesha, Charaka, Drudabala, Chakrapanidatta. Sutra Sthana, Chapter 27, Verse. 297. In: Acharya Y T(Edi.), Charaka Samhita with Ayurveda Deepika Commentary. Reprint Edition, 2011. Varanasi: Chowkhamba Surabharati Prakashan: 2011.p.170.

\section{Source of Support: Nil \\ Conflict of Interest: None Declared}

How to cite this URL: S Jagadesh Kumar et al: Efficacy of Erandamooladi Basti In The Management Of Janu Sandhigatavata Vis-A-Vis Osteoarthritis Of Knee Joint - An Observational Clinical Study. International Ayurvedic Medical Journal \{online\} 2021 \{cited February, 2021\} Available from: http://www.iamj.in/posts/images/upload/360 366.pdf 